\title{
Vascular Aspects in Glaucoma: From Pathogenesis to Therapeutic Approaches
}

\author{
Anna-Sophie Mursch-Edlmayr, Matthias Bolz and Clemens Strohmaier *
}

check for updates

Citation: Mursch-Edlmayr, A.-S.; Bolz, M.; Strohmaier, C. Vascular Aspects in Glaucoma: From Pathogenesis to Therapeutic Approaches. Int. J. Mol. Sci. 2021, 22, 4662. https://doi.org/10.3390/ ijms22094662

Academic Editor: Giacinto Bagetta

Received: 31 March 2021

Accepted: 25 April 2021

Published: 28 April 2021

Publisher's Note: MDPI stays neutral with regard to jurisdictional claims in published maps and institutional affiliations.

Copyright: (c) 2021 by the authors. Licensee MDPI, Basel, Switzerland. This article is an open access article distributed under the terms and conditions of the Creative Commons Attribution (CC BY) license (https:// creativecommons.org/licenses/by/ $4.0 /)$.
Department of Ophthalmology/Optometry, Johannes Kepler University, 4020 Linz, Austria; anna-sophie.mursch-edlmayr@kepleruniklinikum.at (A.-S.M.-E.); matthias.bolz@kepleruniklinikum.at (M.B.)

* Correspondence: clemens.strohmaier@kepleruniklinikum.at; Tel.: +43-5-7680-83 (ext. 78408)

\begin{abstract}
Glaucomatous optic neuropathies have been regarded as diseases caused by high intraocular pressure for a long time, despite the concept of vascular glaucoma dating back to von Graefe in 1854. Since then, a tremendous amount of knowledge about the ocular vasculature has been gained; cohort studies have established new vascular risk factors for glaucoma as well as identifying protective measures acting on blood vessels. The knowledge about the physiology and pathophysiology of the choroidal, retinal, as well as ciliary and episcleral circulation has also advanced. Only recently have novel drugs based on that knowledge been approved for clinical use, with more to follow. This review provides an overview of the current vascular concepts in glaucoma, ranging from novel pathogenesis insights to promising therapeutic approaches, covering the supply of the optic nerve head as well as the aqueous humor production and drainage system.
\end{abstract}

Keywords: glaucoma; blood flow; intraocular pressure

\section{Introduction}

Glaucoma (or glaucomatous optic neuropathy, GON) refers to a group of diseases characterized by retinal ganglion cell atrophy with corresponding visual field defects. If unrecognized or untreated, glaucoma can lead to severe visual impairment. It is amongst the most frequent causes of blindness in industrialized countries [1].

Elevated intraocular pressure (IOP) is the most important risk factor for glaucoma, and lowering it is the only proven treatment to date [2-5]. Besides elevated IOP, vascular abnormalities have been recognized as a possible cause for GON, with the concept of vascular glaucoma dating back almost 170 years [6]. Those 170 years have brought along many advances in the understanding of the vascular aspect of glaucoma: cohort studies have established new vascular risk factors as well as identifying protective measures acting on blood vessels. New technologies enable a more refined investigation of the ocular vascular beds, steadily increasing our understanding of the physiology and pathophysiology. Only recently have novel drugs based on that knowledge been approved for clinical use, with more to follow.

This review aims to provide an overview of selected vascular aspects in glaucoma, covering vascular risk factors in epidemiological studies as well as physiological aspects in animal models and abnormal vascular findings in glaucoma patients.

\section{Vascular Risk Factors from Cohort Studies}

Several cohort studies conducted in different populations have identified vascular risk factors for various aspects of glaucoma, but findings are inconsistent.

Low ocular perfusion pressure (OPP, either mean OPP or diastolic OPP, or both) has been identified as a risk factor for OAG in the Los Angeles Latino Eye Study [7], the EgnaNeumarkt Study [8], the Singapore Eye Study [9], and the Barbados Eye Study [2,10]. The Early Manifest Glaucoma Trial identified low systolic perfusion pressure as a risk factor for 
disease progression independent of IOP [4]. Surprisingly, other studies did not confirm an association of low systolic perfusion pressure with NTG or OAG with low IOP [8].

A recent meta-analysis found a consistent association of low perfusion pressure and POAG but not NTG [11], even though some large epidemiologic studies were excluded due to mode of data reporting. The Leuven Eye Study found higher mean OPP values in glaucoma patients in a cross-sectional design [12].

An important caveat is the heterogeneity of the blood pressure (BP)-related formulas used in different studies. A report by Barbosa-Breda et al. found differences of up to $100 \%$ for the obtained OPP values depending on the applied formula [13]. Furthermore, ocular perfusion pressure is commonly calculated using arterial blood pressure and IOP (see the next section for a more detailed discussion), and its dependence on IOP was reported with inconsistent findings $[7,14]$.

\section{Ocular Blood Supply and Ocular Perfusion Pressure}

The blood supply of the ocular tissues arises from the ophthalmic artery, the first major branch of the internal carotid artery, as it supplies the human orbit. The ocular branches of the ophthalmic artery can be divided into the central retinal artery and the posterior and anterior ciliary arteries [15]. The central retinal artery supplies the retina as well as the superficial layers of the optic nerve head $(\mathrm{ONH})$. The posterior ciliary arteries divide in the long (LPCAs) and short posterior arteries (SPCAs). The former supply the iris, the ciliary body, and the anterior choroidal tissue, whereas the latter feed the posterior choroid and the largest part of the anterior $\mathrm{ONH}[15,16]$. The anterior ciliary arteries are responsible for supplying blood flow to the anterior uvea. Blood supply of the ONH is complex as it can be stratified into four layers (Figure 1). The superficial nerve fiber layer consists mainly of the axons of the retinal ganglion cells and is supplied by the inner retinal circulation. The prelaminar region of ONH receives its blood supply from the branches of the peripapillary choroid and from the SPCAs. The third layer is the lamina cribrosa (LC), which is exclusively supplied by the SPCAs. The retrolaminar region located outside the globe is nourished by both the pial vessels and the SPCAs [17].

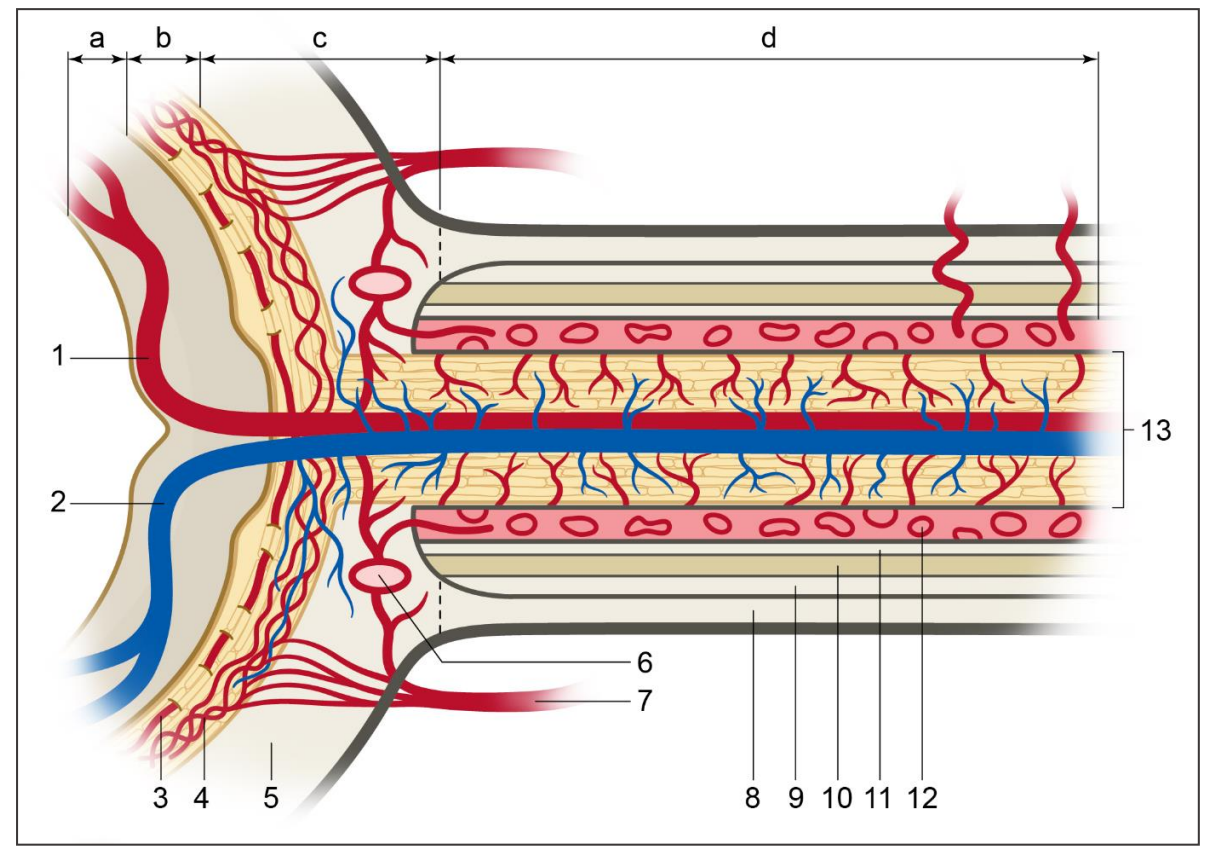

Figure 1. (a) Different areas of perfusion of the optic nerve head showing a superficial nerve fiber layer, (b) prelaminar region, (c) laminar region, (d) retrolaminar region, (1) central retinal artery, (2) central retinal vein, (3) retina, (4) choroid, (5) sclera, (6) circle of Zinn-Haller, (7) short posterior ciliary arteries, (8) optic nerve sheath (9) subdural cavity, (10) arachnoid mater, (11) subarachnoidal space, (12) pia mater, (13) optic nerve. 
As in any tissue of the body, arterial blood pressure drives blood through the vasculature, and the combined resistance of all vessels causes a pressure drop at the venous side of the circulation (i.e., the vortex veins or the orbital veins in the case of episcleral vessels). A major difference to most circulations, however, is the compressing force exerted by intraocular pressure (IOP). This causes the vortex veins to behave as Starling resistors, i.e., maintaining an intraluminal pressure slightly higher than IOP to prevent them from collapsing. Figure 2 illustrates the effect of intraocular pressure (as an external compression force) on the flow and transmural pressure in an intraocular vessel [18].
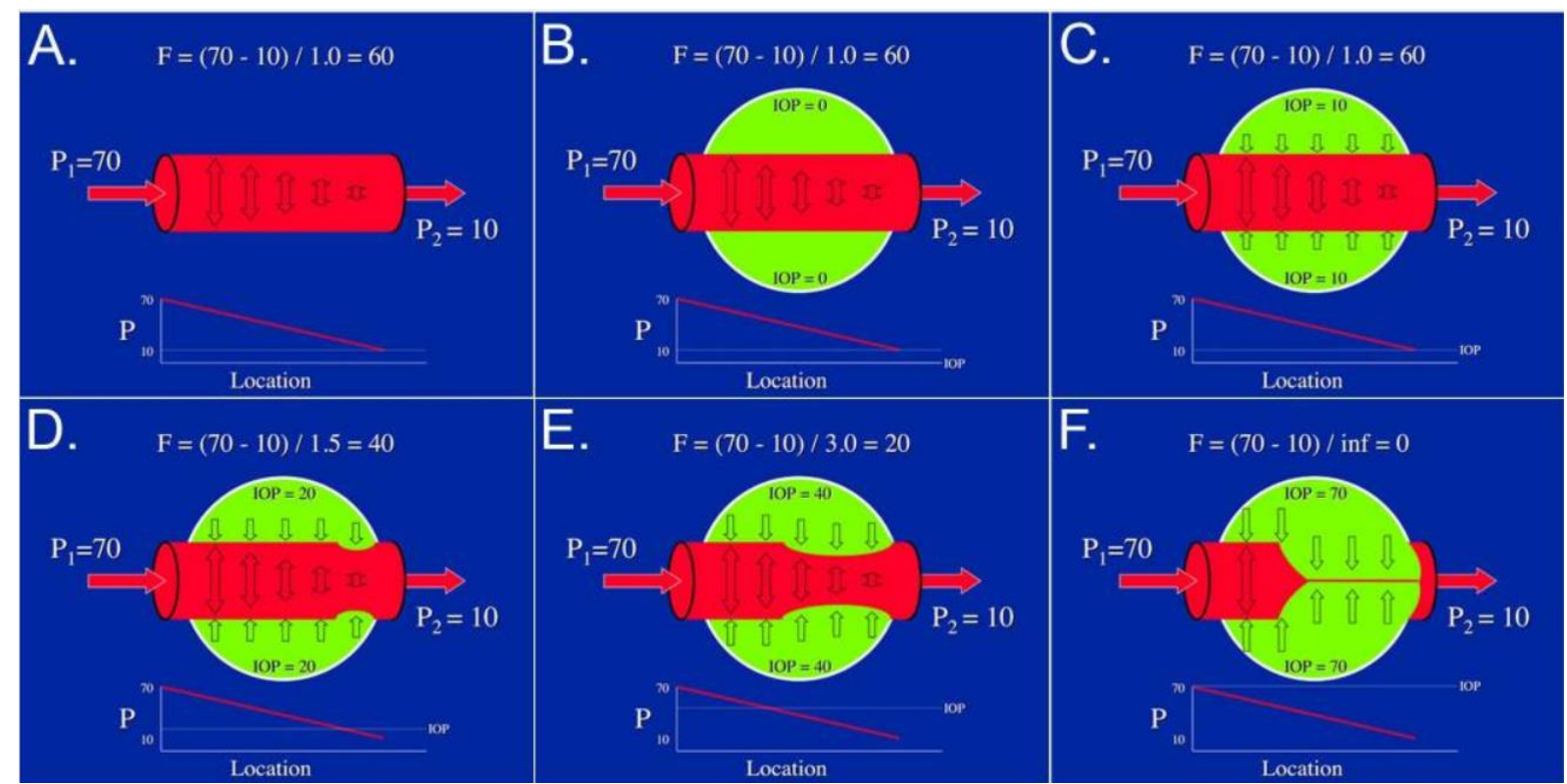

Figure 2. Ocular Starling resistor. (A) Vessel flow (F) is a function of the pressure gradient (P1-P2) along the vessel divided by the resistance. (B,C) If the vessel passes through an organ (e.g., the eye) with a low tissue pressure (e.g., IOP), the pressure inside the vessel exceeds the pressure outside the vessel (i.e., the transmural pressure gradient) and so the vessel remains distended. $(\mathbf{D}, \mathbf{E})$ If the tissue pressure is somewhat higher and exceeds the pressure at the lowest point inside the vessel (i.e., at the "venous" end), that region of the vessel will begin to collapse. This will increase the resistance to flow in that segment, thereby raising the intraluminal pressure until the transmural pressure becomes slightly positive again. (F) If the tissue pressure becomes greater than the arterial input pressure, the vessel will collapse completely, the resistance will be infinite, and flow through the vessel will cease. Reproduced with permission from [18].

Assuming that the venous pressure must be slightly higher than the intraocular pressure, the ocular perfusion pressure (i.e., the pressure gradient driving blood flow) is commonly approximated by the following formula [19]:

$$
\mathrm{OPP}=\mathrm{MAP}-\mathrm{IOP}
$$

(MAP = mean arterial pressure).

This approximation, however, might not be accurate in clinically relevant pressure ranges. There is some evidence suggesting that the Starling resistor behavior outlined above may produce non-linear results, especially at low IOP values. Maepea was the first to note that choroidal venous pressure appears to be significantly higher than IOP at low IOP values [19].

Currently, human in vivo measurements of retinal or choroidal venous pressure are technically not possible, despite approximations of retinal venous pressure existing with ophthalmodynamometry [20]. Unpublished data obtained in a rabbit model, kindly provided by Reitsamer, on the relationship between IOP and choroidal venous pressure showed that with IOP values in a normal range, choroidal venous pressure clearly deviates 
from the assumed 1:1 relationship; thus, perfusion pressure in the choroid is less than estimated by the PP = MAP - IOP formula (Figure 3). From a clinical perspective, this is of high relevance in normal tension glaucoma, where low (diastolic) blood pressure might cause insufficient blood supply of the optic nerve head. Furthermore, this might cause an overestimation of perfusion pressure in clinical studies.

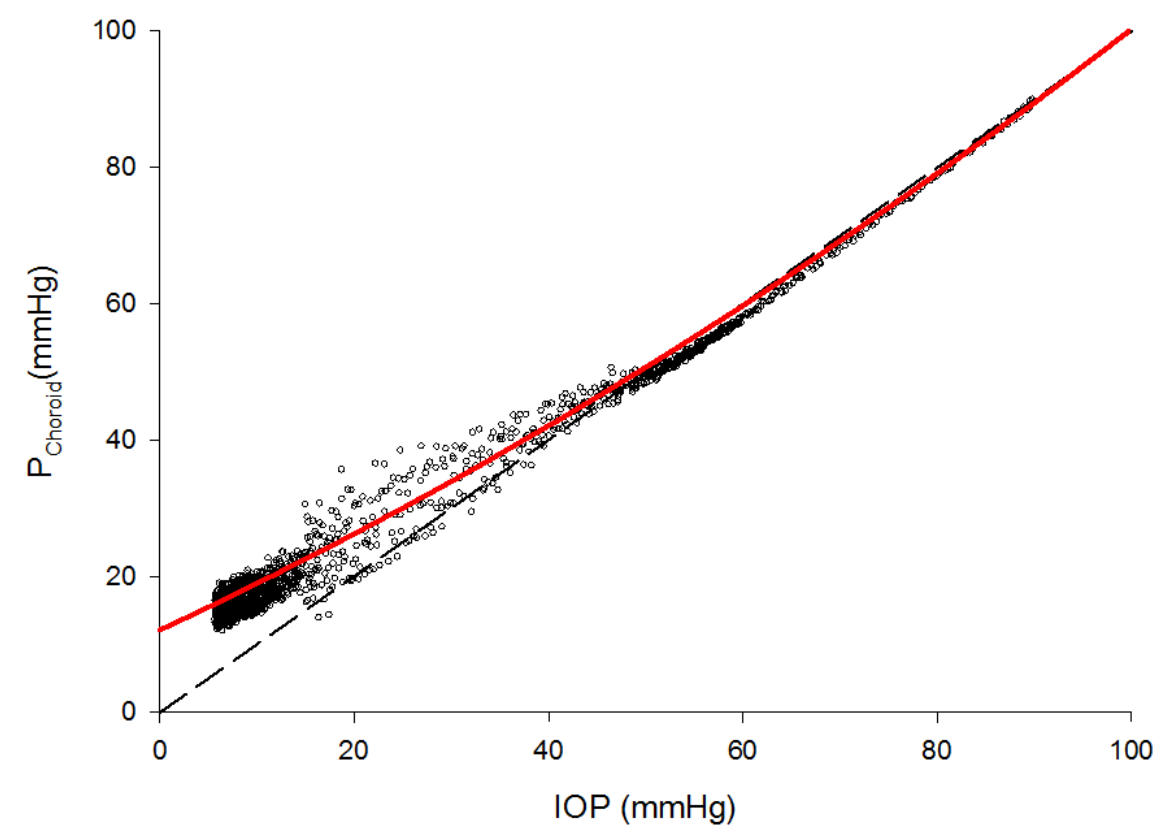

Figure 3. Relationship between intraocular pressure (IOP) and choroidal venous pressure (P choroid). As expected by the Starling resistor effect, choroidal venous pressure slightly exceeds intraocular pressure at medium to high IOP values. At lower IOP values, however, choroidal venous pressure deviates from this 1:1 relationship significantly, reaching $50 \%$ at values below $10 \mathrm{mmHg}$ (unpublished observation by Reitsamer). Each dot represents a single pressure measurement, the red line represents a curve-fit of all measurement values.

\section{Regulation of Ocular Blood Flow}

The arteries of the choroid, retina, ciliary body, and optic nerve head circulations are all capable of active vascular resistance regulation, commonly termed autoregulation [21-25]. This includes adaptions to metabolic changes (metabolic autoregulation) and adaptions to changes in transmural pressure (myogenic autoregulation), as well as neuronal autoregulation, a somewhat broader term including both paracrine and neurohumoral regulatory mechanisms $[18,21,26-28]$. The orbital veins, on the other hand, exhibit a passive behavior during perfusion pressure changes [29]. A striking clinical example is the immediate choroidal thickness increase during the Valsalva maneuver [30], resulting in increased intraocular pressure. Passive venous behavior also implies an effect of elevated thoracic pressure, as it occurs in obstructive sleep apnea syndrome as well as in obesity, on the ocular circulation. Orbital veins are difficult to measure in most species with the exception of rabbits, where a foramen in the scull allows direct cannulation [29]. Interestingly, in this model, a linear relationship between orbital venous pressure and mean arterial blood pressure was found.

\section{Episcleral Circulation and Episcleral Venous Pressure}

The episcleral circulation is of high relevance for glaucoma because of its impact on intraocular pressure. Steady-state intraocular pressure (IOP) can be described by the Goldmann equation as the relationship between aqueous flow, uveoscleral outflow, outflow facility, and episcleral venous pressure (EVP) as an additive factor [31]. EVP is the pressure that has to be overcome by fluid to leave the eye via the conventional (trabecular) 
outflow pathway and, therefore, is an important determinant of steady-state IOP. The anatomical organization of the episcleral vessels appears to be well suited for regulation of the pressure in the episcleral veins and thereby IOP, as the episcleral circulation is mostly devoid of capillaries and arteries, and veins are connected through anastomoses [32,33]. More interestingly, these anastomoses are supplied by nerves, whose nerve endings stain positively for autonomic neurotransmitters [34]. A study by Zamora and Kiel confirmed Ascher's original observation that the episcleral circulation responds to topical anesthetics in a rabbit model [35]; however, this could not be replicated in humans [36]. Additional data supporting the assumption that the EVP is not passive, but actively regulated, came from a study investigating EVP changes during changes in body posture, where EVP changed less than predicted by the hydrostatic water column effect [37]. To date, the functional significance of the innervation of the episcleral circulation is only scarcely investigated, most likely due to technical reasons. However, one study reported changes in EVP in response to stimulation of a brain stem nucleus [38], thus indicating the possibility for active regulation.

The therapeutic potential of the episcleral circulation was recently confirmed in an experimental study with cromakalim prodrug 1 (CKLP1) in a mouse model. CKLP1 reduces EVP and thereby EVP-as predicted by the Goldmann equation. This effect is additive to other known substances acting on aqueous humor formation [39].

\section{Measurement of Ocular Blood Flow}

Non-invasive measurement of ocular perfusion has been the focus of intense research interest in recent decades. A wide range of techniques all utilizing the Doppler effect have been introduced (Table 1). The Doppler effect describes the phenomenon of change in frequency and wavelength of a wave caused by the change in distance between the creator and observer of the wave. For light, this causes a shift in color. The faster the creator is moving towards the observer, the greater the blue shift, whereas sound becomes higher in pitch. In vascularized tissue, the Doppler effect is caused by moving red blood cells within the vessels [40]. With adequate technical equipment, the change in frequency or wavelength can be detected and computed into parameters describing perfusion. Absolute measurements of perfusion are only obtained if information on the vessel diameter is provided, taking into account the Hagen-Poiseuille equation.

Ultrasound-based color Doppler imaging is the only technology that measures the Doppler shifts in sound waves, whereas other techniques such as laser Doppler flowmetry, laser Doppler velocimetry, and Doppler optical coherence tomography use laser light (see Table 1).

Some of the techniques to measure perfusion of the $\mathrm{ONH}$ are limited to superficial tissue, supplied by the central retinal artery, but results from an animal model suggest that not only the superficial but also the deep ONH vascular supply is associated with pathologic changes in glaucoma [41]. Contributions from deeper ONH layers to the signal vary depending on the techniques, as different wavelength light sources are used [42] (see Table 1).

The laser speckle flowgraphy (LSFG) method is based on the laser speckle phenomenon. It describes an interference phenomenon occurring when a diffusing surface (e.g., the ocular fundus) is illuminated by a coherent light source (i.e., a laser). The backscattered light has the appearance of a granular pattern (i.e., the speckle pattern), which is entirely random and can only be described statistically [43]. In the case of moving scatters (e.g., red blood cells) within the illuminated field of view, the appearance of the speckle pattern changes rapidly; the greater the blood velocity, the higher the rate of variation in the speckle pattern in the vascular area and the lower the speckle contrast [44]. This enables two-dimensional measurements of perfusion at the $\mathrm{ONH}$, the retina, and the choroid. 
Table 1. Overview of different technologies to measure ocular perfusion.

\begin{tabular}{|c|c|c|c|c|c|c|}
\hline Technology & Principle & Outcome Parameter & Measurement Area & Advantages & Limitations & $\begin{array}{l}\text { Penetration Depth } \\
\text { (in Humans) }\end{array}$ \\
\hline $\begin{array}{l}\text { Laser Doppler Flowmetry } \\
\text { (LDF) }\end{array}$ & Laser $(780 \mathrm{~nm})$ & $\begin{array}{l}\text { Mean Velocity } \\
\text { Volume } \\
\text { Flow }\end{array}$ & $100 \times 100-400 \times 400 \mu \mathrm{m}$ & $\begin{array}{l}\text { Commercially available } \\
\text { Valid reproducibility [45] }\end{array}$ & No absolute measurements & $300-400 \mu \mathrm{m}[46]$ \\
\hline $\begin{array}{l}\text { Laser Doppler Velocimetry } \\
\text { (LDV) }\end{array}$ & Laser (675 nm) & Maximal Velocity & $\begin{array}{l}\text { Individual retinal } \\
\text { arterioles/venules }\end{array}$ & $\begin{array}{l}\text { Absolute measurements } \\
\text { Commercially available }\end{array}$ & $\begin{array}{c}\text { Prone to eye movements } \\
\text { Complex and } \\
\text { time-consuming } \\
\text { measurements } \\
\text { No OHN measurements }\end{array}$ & $0.5-0.8 \mathrm{~mm}[47]$ \\
\hline $\begin{array}{l}\text { Color Doppler Imaging } \\
\text { (CDI) }\end{array}$ & $\begin{array}{c}\text { Ultrasound (Doppler with } \\
6.5 \mathrm{MHz})\end{array}$ & $\begin{array}{c}\text { Peak systolic velocity (PSV) } \\
\text { End diastolic velocity (EDV) } \\
\text { Mean flow velocity (MFV) } \\
\text { Resistivity index (RI) }\end{array}$ & $\begin{array}{c}\text { Retrobulbar arteries } \\
\text { (ophthalmic artery, retinal } \\
\text { central artery, short posterior } \\
\text { ciliary artery) }\end{array}$ & Commercially available & $\begin{array}{c}\text { Time-consuming } \\
\text { Limited to retrobulbar } \\
\text { arteries } \\
\text { No absolute measurements } \\
\text { No measurement standard } \\
\text { Patient in supine position } \\
\text { during measurement }\end{array}$ & Retrobulbar \\
\hline Doppler OCT (D-OCT) & Laser (841 nm) & Total volumetric RBF & Retinal vessels & Absolute measurement & $\begin{array}{c}\text { Prone to artefacts due to eye } \\
\text { movement } \\
\text { Not commercially available }\end{array}$ & $1-2 \mathrm{~mm}[47]$ \\
\hline
\end{tabular}




\section{Hemodynamic Alterations in Glaucoma Patients}

With color Doppler imaging, reduced blood flow velocities in retrobulbar vessels were shown in both high- and low-tension POAG patients compared with healthy control subjects $[12,48,49]$. The use of laser Doppler velocimetry revealed that blood flow in the peripapillary capillaries, nourishing the superficial nerve fiber layer of the $\mathrm{ONH}$, was reduced in patients with OAG and NTG when compared with a healthy group [50]. Results from scanning laser Doppler flowmetry (LDF) measurements in the disc cup and the neuroretinal rim showed significantly reduced perfusion in patients with high tension POAG compared with healthy subjects, as well as subjects with ocular hypertension [51-53]. Further, results obtained with LDF suggested a correlation of glaucomatous damage with reduced ONH perfusion [54].

Much attention has been given to the technology of OCT angiography [55]. However, it should be noted that this technology is unable to measure flow or perfusion but rather gives information about vessel density.

Studies reporting results from LSFG measurements in eyes with normal tension POAG have been published for over a decade. Significant differences in $\mathrm{ONH}$ perfusion have been shown between patients with normal tension glaucoma and healthy individuals [56,57].

All reported studies above were conducted as cross-sectional trials. Results of a prospective, longitudinal study on structure rather than perfusion, comparing healthy individuals with patients with preperimetric glaucoma and glaucoma patients with visual field defects, have indicated that macular vessel density measured with OCT angiography declined faster than the ganglion cell thickness [58]. Longitudinal data regarding $\mathrm{ONH}$ perfusion in glaucoma came from a primate glaucoma model. Cull et al. performed a study to evaluate longitudinal changes in ONH blood flow with LSFG. They showed that basal $\mathrm{ONH}$ BF was strongly associated with the stage of glaucoma severity (measured by loss of RNFLT) and report a two-phase pattern of change. During the earliest stage of glaucoma, ONH blood flow exhibited a mild increase, after which it progressively declined with an increasing degree of glaucoma severity. When more than $40 \%$ of the RNFLT was lost, ONH blood flow was reduced by $25 \%$ below baseline [59]. The initial increase in ONH blood flow was confirmed by results from a cross-sectional study in humans [60].

Until recently, only one longitudinal study reported changes in optic nerve head perfusion over time in humans. In 2005, Martínez et al. published results from a longitudinal trial where they observed 49 patients with high tension POAG over 36 months. In total, 23 eyes had progressed during the study period. The authors identified increased resistivity in the ophthalmic artery and the short posterior ciliary arteries as risk factors for the progression of glaucomatous visual field defects [61]. In 2020, a retrospective, longitudinal study was published, which included 350 eyes of 225 POAG patients. The authors found older age, high pulse rate, and whether the damaged quadrant was superior or temporal to be risk factors for faster perfusion parameter deterioration. When two or more risk factors were obtained, MT decrease preceded RNFLT decrease [62]. This finding indicates that in a subgroup of glaucoma patients, reduced ONH perfusion is part of the pathogenesis.

\section{Novel Therapeutic Approaches for the Vascular Aspects of Glaucoma}

Currently, there is no established therapy specifically addressing the choroidal or optic nerve head vasculature. Some IOP-lowering agents at least partly act through vasoconstriction in the ciliary body vasculature [63]. One interesting observation, however, hints towards a therapeutic potential for drugs acting on the ocular vasculature: increased oral uptake of dietary NO donors reduced the incidence of parafoveal visual field defects in a large cohort study [64].

Furthermore, the episcleral circulation recently emerged as a therapeutic target of new classes of IOP-lowering drugs as well as new routes of administration of existing drug classes.

Rho-kinase inhibitors are a novel drug class for glaucoma treatment for which FDA approval was received in 2017 [65]. They act at least partly through increasing outflow 
facility in the conventional (trabecular) pathway [66,67]. Additionally, an EVP-lowering effect has been shown for some Rho-kinase inhibitors in an animal model [68]. The clinical significance of the EVP-lowering effect is not entirely clear, but a combined mechanism is likely, as the magnitude of IOP decrease cannot be explained by either mechanism alone in humans [69].

Another well-established drug class has an effect on the ocular vasculature. Prostaglandin analogs (PGAs) are an established drug class for glaucoma treatment [70], increasing uveoscleral outflow to lower IOP. Recent studies, however, revealed that PGAs show a different dose-response relationship depending on their route of administration (reviewed in [71]). Current data suggest this is due to the opposing effects of prostaglandin analogs on the uveoscleral outflow pathway as well as the episcleral venous pressure [72,73]. While the IOP-lowering effect of topical prostaglandins appears to be limited by the opposing effect of increasing EVP, intracameral prostaglandins seem to dodge this limitation [74]. It is important to note that these observations are based on animal models and need further verification in clinical trials.

In summary, both defining and treating possible vascular glaucoma triggers remain challenging in clinical routine as well as from a scientific point of view. Emerging technologies to measure ocular perfusion (e.g., Doppler OCT or LSFG) in vivo have the potential to further elucidate the role of the ocular perfusion in the pathophysiology of glaucoma. Furthermore, current drug development utilizes obtained knowledge on the ocular vasculature and will likely be available in clinical practice soon.

Author Contributions: Conceptualization: A.-S.M.-E., C.S.; writing-original draft preparation: A.-S.M.-E., C.S.; writing-review and editing: M.B. All authors have read and agreed to the published version of the manuscript.

Funding: This research received no external funding.

Institutional Review Board Statement: Not applicable.

Informed Consent Statement: Not applicable.

Acknowledgments: Aron Cserveny's help in creating some illustrations is gratefully acknowledged. Open Access Funding by the University of Linz.

Conflicts of Interest: The authors declare no conflict of interest.

\section{References}

1. Kapetanakis, V.V.; Chan, M.P.Y.; Foster, P.J.; Cook, D.G.; Owen, C.G.; Rudnicka, A.R. Global variations and time trends in the prevalence of primary open angle glaucoma (POAG): A systematic review and meta-analysis. Br. J. Ophthalmol. 2016, 100, 86-93. [CrossRef]

2. Leske, M.C.; Wu, S.-Y.; Hennis, A.; Honkanen, R.; Nemesure, B.; BESs Study Group. Risk factors for incident open-angle glaucoma: The Barbados Eye Studies. Ophthalmology 2008, 115, 85-93. [CrossRef]

3. Schulzer, M. Intraocular pressure reduction in normal-tension glaucoma patients. The Normal Tension Glaucoma Study Group. Ophthalmology 1992, 99, 1468-1470. [CrossRef]

4. Leske, M.C.; Heijl, A.; Hyman, L.; Bengtsson, B.; Dong, L.M.; Yang, Z.; EMGT Group. Predictors of long-term progression in the early manifest glaucoma trial. Ophthalmology 2007, 114, 1965-1972. [CrossRef] [PubMed]

5. Sommer, A.; Tielsch, J.M.; Katz, J.; Quigley, H.A.; Gottsch, J.D.; Javitt, J.; Singh, K. Relationship between intraocular pressure and primary open angle glaucoma among white and black Americans. The Baltimore Eye Survey. Arch. Ophthalmol. 1991, 109, 1090-1095. [CrossRef] [PubMed]

6. von Graefe, A. Vorläufige Notiz über das Wesen des Glaukoms. Arch. Ophthalmol. 1854, 1, 374.

7. Memarzadeh, F.; Ying-Lai, M.; Chung, J.; Azen, S.P.; Varma, R. Blood pressure, perfusion pressure, and open-angle glaucoma: The Los Angeles Latino eye study. Investig. Ophthalmol. Vis. Sci. 2010, 51, 2872-2877. [CrossRef] [PubMed]

8. Bonomi, L.; Marchini, G.; Marraffa, M.; Bernardi, P.; Morbio, R.; Varotto, A. Vascular risk factors for primary open angle glaucoma: The Egna-Neumarkt Study. Ophthalmology 2000, 107, 1287-1293. [CrossRef]

9. Zheng, Y.; Wong, T.Y.; Mitchell, P.; Friedman, D.S.; He, M.; Aung, T. Distribution of Ocular Perfusion Pressure and Its Relationship with Open-Angle Glaucoma: The Singapore Malay Eye Study. Investig. Opthalmol. Vis. Sci. 2010, 51, 3399. [CrossRef]

10. Leske, M.C.; Connell, A.M.; Wu, S.Y.; Hyman, L.G.; Schachat, A.P. Risk factors for open-angle glaucoma. The Barbados Eye Study. Arch. Ophthalmol. 1995, 113, 918-924. [CrossRef] 
11. Kim, K.E.; Oh, S.; Baek, S.U.; Ahn, S.J.; Park, K.H.; Jeoung, J.W. Ocular Perfusion Pressure and the Risk of Open-Angle Glaucoma: Systematic Review and Meta-analysis. Sci. Rep. 2020, 10, 10056. [CrossRef] [PubMed]

12. Abegão Pinto, L.; Willekens, K.; Van Keer, K.; Shibesh, A.; Molenberghs, G.; Vandewalle, E.; Stalmans, I. Ocular blood flow in glaucoma-The Leuven Eye Study. Acta Ophthalmol. 2016, 94, 592-598. [CrossRef] [PubMed]

13. Barbosa-Breda, J.; Abegão-Pinto, L.; Van Keer, K.; Jesus, D.A.; Lemmens, S.; Vandewalle, E.; Rocha-Sousa, A.; Stalmans, I. Heterogeneity in arterial hypertension and ocular perfusion pressure definitions: Towards a consensus on blood pressure-related parameters for glaucoma studies. Acta Ophthalmol. 2019, 97, e487-e492. [CrossRef]

14. Ramdas, W.D.; Wolfs, R.C.W.; Hofman, A.; de Jong Paulus, T.V.M.; Vingerling, J.R.; Jansonius, N.M. Ocular perfusion pressure and the incidence of glaucoma: Real effect or Artifact?: The Rotterdam study. Investig. Ophthalmol. Vis. Sci. 2011, 52, 6875-6881. [CrossRef]

15. Hayreh, S.S. The blood supply of the optic nerve head and the evaluation of it-Myth and reality. Prog. Retin. Eye Res. 2001, 20, 563-593. [CrossRef]

16. Hayreh, S.S. Physiological anatomy of the choroidal vascular bed. Int. Ophthalmol. 1983, 6, 85-93. [CrossRef]

17. Mackenzie, P.J.; Cioffi, G.A. Vascular anatomy of the optic nerve head. Can. J. Ophthalmol. 2008, 43, 308-312. [CrossRef]

18. Kiel, J.W. (Ed.) The Ocular Circulation; Morgan \& Claypool Life Sciences: San Rafael, CA, USA, 2010.

19. Mäepea, O.; Maepea, O. Pressures in the anterior ciliary arteries, choroidal veins and choriocapillaris. Exp. Eye Res. 1992, 54, 731-736. [CrossRef]

20. Lobstein, A.; Nordmann, J. Modern ophthalmodynamometry. Doc. Ophthalmol. 1959, 13, 397-430. [CrossRef]

21. Schmidl, D.; Garhofer, G.; Schmetterer, L. The complex interaction between ocular perfusion pressure and ocular blood flowRelevance for glaucoma. Exp. Eye Res. 2011, 93, 141-155. [CrossRef]

22. Riva, C.E.; Titze, P.; Hero, M.; Petrig, B.L. Effect of acute decreases of perfusion pressure on choroidal blood flow in humans. Investig. Ophthalmol. Vis. Sci. 1997, 38, 1752-1760.

23. Reitsamer, H.A.; Kiel, J.W. Relationship between ciliary blood flow and aqueous production in rabbits. Investig. Ophthalmol. Vis. Sci. 2003, 44, 3967-3971. [CrossRef]

24. Schmetterer, L.; Kiel, J. (Eds.) Ocular Blood Flow; Springer: Berlin/Heidelberg, Germany, 2012; ISBN 978-3-540-69468-7.

25. Schmetterer, L.; Polak, K. Role of nitric oxide in the control of ocular blood flow. Prog. Retin. Eye Res. 2001, 20, 823-847. [CrossRef]

26. Bill, A. Autonomic nervous control of uveal blood flow. Acta Physiol. Scand. 1962, 56, 70-81. [CrossRef]

27. Bill, A. Circulation in the Eye. In Handbook of Physiology; Renkin, E.M., Michel, C.C., Eds.; Waverly Press: Baltimore, MD, USA, 1984; pp. 1001-1034.

28. Johnson, P.C. The myogenic response. In Handbook of Physiology: The Cardiovascular System; Bohr, D.F., Somlyo, A.P., Sparks, H.V., Eds.; Waverly Press: Baltimore, MD, USA, 1980; Volume 2, pp. 409-442.

29. Reitsamer, H.A.; Kiel, J.W. A rabbit model to study orbital venous pressure, intraocular pressure, and ocular hemodynamics simultaneously. Investig. Ophthalmol. Vis. Sci. 2002, 43, 3728-3734.

30. Kurultay-Ersan, I.; Emre, S. Impact of Valsalva Maneuver on Central Choroid, Central Macula, and Disk Fiber Layer Thickness Among High Myopic and Hyperopic Patients. Eur. J. Ophthalmol. 2017, 27, 331-335. [CrossRef]

31. Goldmann, H. Out-flow pressure, minute volume and resistance of the anterior chamber flow in man. Doc. Ophthalmol. 1951, 5-6, 278-356. [CrossRef]

32. Selbach, J.M.; Rohen, J.W.; Steuhl, K.P.; Lutjen-Drecoll, E.; Lütjen-Drecoll, E. Angioarchitecture and innervation of the primate anterior episclera. Curr. Eye Res. 2005, 30, 337-344. [CrossRef] [PubMed]

33. Selbach, M.J.; Schonfelder, U.; Funk, R.H. Arteriovenous anastomoses of the episcleral vasculature in the rabbit and rat eye. J. Glaucoma 1998, 7, 50-57. [CrossRef]

34. Ladek, A.M.A.M.; Trost, A.; Bruckner, D.; Schroedl, F.; Kaser-Eichberger, A.; Lenzhofer, M.; Reitsamer, H.A.H.A.; Strohmaier, C.A.C.A. Immunohistochemical Characterization of Neurotransmitters in the Episcleral Circulation in Rats. Investig. Ophthalmol. Vis. Sci. 2019, 60, 3215. [CrossRef]

35. Zamora, D.O.; Kiel, J.W. Topical Proparacaine and Episcleral Venous Pressure in the Rabbit. Investig. Ophthalmol. Vis. Sci. 2009, 50, 2949. [CrossRef] [PubMed]

36. Malihi, M.; McLaren, J.W.; Sit, A.J. Effect of topical anesthesia on episcleral venous pressure in normal human subjects. Investig. Ophthalmol. Vis. Sci. 2015, 56, 2968-2970. [CrossRef]

37. Lavery, W.J.J.; Kiel, J.W.W. Effects of head down tilt on episcleral venous pressure in a rabbit model. Exp. Eye Res. 2013, 111, 88-94. [CrossRef]

38. Strohmaier, C.A.; Reitsamer, H.A.; Kiel, J.W. Episcleral venous pressure and IOP responses to central electrical stimulation in the rat. Investig. Ophthalmol. Vis. Sci. 2013, 54, 6860-6866. [CrossRef] [PubMed]

39. Chowdhury, U.R.; Rinkoski, T.A.; Bahler, C.K.; Millar, J.C.; Bertrand, J.A.; Holman, B.H.; Sherwood, J.M.; Overby, D.R.; Stoltz, K.L.; Dosa, P.I.; et al. Effect of cromakalim prodrug 1 (CKLP1) on aqueous humor dynamics and feasibility of combination therapy with existing ocular hypotensive agents. Investig. Ophthalmol. Vis. Sci. 2017, 58, 5731-5742. [CrossRef]

40. Bonner, R.; Nossal, R.; Shepherd, A.P. Principles of Laser Doppler Flowmetry; Shepherd, A.P., Oberg, P.A., Eds.; Kluwer Academic Publishers: Berlin, Germany, 1990. 
41. Wang, L.; Cull, G.A.; Piper, C.; Burgoyne, C.F.; Fortune, B. Anterior and posterior optic nerve head blood flow in nonhuman primate experimental glaucoma model measured by laser speckle imaging technique and microsphere method. Investig. Ophthalmol. Vis. Sci. 2012, 53, 8303-8309. [CrossRef]

42. Petrig, B.L.; Riva, C.E.; Hayreh, S.S. Laser Doppler flowmetry and optic nerve head blood flow. Am. J. Ophthalmol. 1999, 127, 413-425. [CrossRef]

43. Sugiyama, T.; Araie, M.; Riva, C.E.; Schmetterer, L.; Orgul, S. Use of laser speckle flowgraphy in ocular blood flow research. Acta Ophthalmol. 2010, 88, 723-729. [CrossRef]

44. Ruth, B. Blood flow determination by the laser speckle method. Int. J. Microcirc. Clin. Exp. 1990, 9, $21-45$.

45. Strenn, K.; Menapace, R.; Rainer, G.; Findl, O.; Wolzt, M.; Schmetterer, L. Reproducibility and sensitivity of scanning laser Doppler flowmetry during graded changes in PO2. Br. J. Ophthalmol. 1997, 81, 360-364. [CrossRef] [PubMed]

46. Sehi, M. Basic technique and anatomically imposed limitations of confocal scanning laser Doppler flowmetry at the optic nerve head level. Acta Ophthalmol. 2011, 89, e1-e11. [CrossRef] [PubMed]

47. Li, Y.; Chen, J.; Chen, Z. Advances in Doppler optical coherence tomography and angiography. Transl. Biophotonics $2019,1$. [CrossRef] [PubMed]

48. Garhöfer, G.; Fuchsjäger-Mayrl, G.; Vass, C.; Pemp, B.; Hommer, A.; Schmetterer, L. Retrobulbar blood flow velocities in open angle glaucoma and their association with mean arterial blood pressure. Investig. Ophthalmol. Vis. Sci. 2010, 51, 6652-6657. [CrossRef] [PubMed]

49. Plange, N.; Remky, A.; Arend, O. Colour Doppler imaging and fluorescein filling defects of the optic disc in normal tension glaucoma. Br. J. Ophthalmol. 2003, 87, 731-736. [CrossRef] [PubMed]

50. Hamard, P.; Hamard, H.; Dufaux, J.; Quesnot, S. Optic nerve head blood flow using a laser Doppler velocimeter and haemorheology in primary open angle glaucoma and normal pressure glaucoma. Br. J. Ophthalmol. 1994, 78, 449-453. [CrossRef]

51. Grunwald, J.E.; Piltz, J.; Hariprasad, S.M.; DuPont, J. Optic nerve and choroidal circulation in glaucoma. Investig. Ophthalmol. Vis. Sci. 1998, 39, 2329-2336.

52. Findl, O.; Rainer, G.; Dallinger, S.; Dorner, G.; Polak, K.; Kiss, B.; Georgopoulos, M.; Vass, C.; Schmetterer, L. Assessment of optic disk blood flow in patients with open-angle glaucoma. Am. J. Ophthalmol. 2000, 130, 589-596. [CrossRef]

53. Kerr, J.; Nelson, P.; O'Brien, C. A comparison of ocular blood flow in untreated primary open-angle glaucoma and ocular hypertension. Am. J. Ophthalmol. 1998, 126, 42-51. [CrossRef]

54. Lam, A.; Piltz-Seymour, J.R.; DuPont, J.; Grunwald, J.E. Laser Doppler Flowmetry in Asymmetric Glaucoma. Curr. Eye Res. 2005, 30, 221-227. [CrossRef]

55. Van Melkebeke, L.; Barbosa-Breda, J.; Huygens, M.; Stalmans, I. Optical Coherence Tomography Angiography in Glaucoma: A Review. Ophthalmic. Res. 2018, 60, 139-151. [CrossRef]

56. Mursch-Edlmayr, A.S.; Luft, N.; Podkowinski, D.; Ring, M.; Schmetterer, L.; Bolz, M. Laser speckle flowgraphy derived characteristics of optic nerve head perfusion in normal tension glaucoma and healthy individuals: A Pilot study. Sci. Rep. 2018, 8 , 1-7. [CrossRef]

57. Shiga, Y.; Omodaka, K.; Kunikata, H.; Ryu, M.; Yokoyama, Y.; Tsuda, S.; Asano, T.; Maekawa, S.; Maruyama, K.; Nakazawa, T. Waveform analysis of ocular blood flow and the early detection of normal tension glaucoma. Investig. Ophthalmol. Vis. Sci. 2013, 54, 7699-7706. [CrossRef] [PubMed]

58. Hou, H.; Moghimi, S.; Proudfoot, J.A.; Ghahari, E.; Penteado, R.C.; Bowd, C.; Yang, D.; Weinreb, R.N. Ganglion Cell Complex Thickness and Macular Vessel Density Loss in Primary Open-Angle Glaucoma. Ophthalmology 2020, 127, 1043-1052. [CrossRef] [PubMed]

59. Cull, G.; Burgoyne, C.F.; Fortune, B.; Wang, L. Longitudinal hemodynamic changes within the optic nerve head in experimental glaucoma. Investig. Ophthalmol. Vis. Sci. 2013, 54, 4271-4277. [CrossRef] [PubMed]

60. Gardiner, S.K.; Cull, G.; Fortune, B.; Wang, L. Increased optic nerve head capillary blood flow in early primary open-angle glaucoma. Investig. Ophthalmol. Vis. Sci. 2019, 60, 3110-3118. [CrossRef]

61. Martínez, A.; Sánchez, M. Predictive value of colour Doppler imaging in a prospective study of visual field progression in primary open-angle glaucoma. Acta Ophthalmol. Scand. 2005, 83, 716-722. [CrossRef]

62. Kiyota, N.; Shiga, Y.; Omodaka, K.; Pak, K.; Nakazawa, T. Time-Course Changes in Optic Nerve Head Blood Flow and Retinal Nerve Fiber Layer Thickness in Eyes with Open-angle Glaucoma. Ophthalmology 2020, 128, 663-671. [CrossRef]

63. Reitsamer, H.A.; Posey, M.; Kiel, J.W. Effects of a topical alpha2 adrenergic agonist on ciliary blood flow and aqueous production in rabbits. Exp. Eye Res. 2006, 82, 405-415. [CrossRef]

64. Kang, J.H.; Willett, W.C.; Rosner, B.A.; Buys, E.; Wiggs, J.L.; Pasquale, L.R. Association of Dietary Nitrate Intake With Primary Open-Angle Glaucoma. JAMA Ophthalmol. 2016, 134, 294. [CrossRef]

65. Rhopressa (Netarsudil) Ophthalmic Solution. Available online: https://www.accessdata.fda.gov/drugsatfda_docs/nda/2017/2 08254Orig1s000TOC.cfm (accessed on 2 February 2021).

66. Yang, C.Y.C.; Liu, Y.; Lu, Z.; Ren, R.; Gong, H. Effects of Y27632 on aqueous humor outflow facility with changes in hydrodynamic pattern and morphology in human eyes. Investig. Ophthalmol. Vis. Sci. 2013, 54, 5859-5870. [CrossRef]

67. Ren, R.; Li, G.; Le, T.D.; Kopczynski, C.; Stamer, W.D.; Gong, H. Outflow facility in human eyes through multiple mechanisms. Investig. Ophthalmol. Vis. Sci. 2016, 57, 6197-6209. [CrossRef] 
68. Kiel, J.W.; Kopczynski, C.C. Effect of AR-13324 on episcleral venous pressure in Dutch belted rabbits. J. Ocul. Pharmacol. Ther. 2015, 31, 146-151. [CrossRef]

69. Kazemi, A.; McLaren, J.W.; Kopczynski, C.C.; Heah, T.G.; Novack, G.D.; Sit, A.J. The effects of netarsudil ophthalmic solution on aqueous humor dynamics in a randomized study in humans. J. Ocul. Pharmacol. Ther. 2018, 34, 380-386. [CrossRef] [PubMed]

70. Prum, B.E.; Rosenberg, L.F.; Gedde, S.J.; Mansberger, S.L.; Stein, J.D.; Moroi, S.E.; Herndon, L.W.; Lim, M.C.; Williams, R.D. Primary Open-Angle Glaucoma. Ophthalmology 2016, 123, P41-P111. [CrossRef] [PubMed]

71. Lee, S.S.; Robinson, M.R.; Weinreb, R.N. Episcleral Venous Pressure and the Ocular Hypotensive Effects of Topical and Intracameral Prostaglandin Analogs. J. Glaucoma 2019, 28, 846-857. [CrossRef] [PubMed]

72. Tsai, S.; Miller, P.E.; Struble, C.; Howard, S.; Almazan, A.; Burke, J.A.; Hughes, P.M.; Li, H.; Conforti, P.; Lee, S.S.; et al. Topical application of $0.005 \%$ latanoprost increases episcleral venous pressure in normal dogs. Vet. Ophthalmol. 2012, 15, 71-78. [CrossRef] [PubMed]

73. Lee, S.S.; Burke, J.; Shen, J.; Almazan, A.; Orilla, W.; Hughes, P.; Zhang, J.; Li, H.; Struble, C.; Miller, P.E.; et al. Bimatoprost sustained-release intracameral implant reduces episcleral venous pressure in dogs. Vet. Ophthalmol. 2018, 21, 376-381. [CrossRef] [PubMed]

74. Lee, S.S.; Dibas, M.; Almazan, A.; Robinson, M.R. Dose-Response of Intracameral Bimatoprost Sustained-Release Implant and Topical Bimatoprost in Lowering Intraocular Pressure. J. Ocul. Pharmacol. Ther. 2019, 35, 138-144. [CrossRef] 